\title{
Chromosomal Conspectus and Evolutionary Status of Indian Commercial Timbers (Hardwoods)
}

\author{
Y. S. Bedi \\ Regional Research Laboratory, Extension Centre, \\ Bundla, Palampur-176061, India
}

Accepted August 1, 1991

Except for stray efforts on the improvement of Indian forest trees through selective breeding, grafting, tissue culture, colchiploidy and hybridization in Tectona grandis, Salmalia malabarica, Eucalyptus species, Santalum album, Gmelina arborea, Terminalia myriocarpa and Michelia champaca (Venkatesh and Sharma 1977, Lakshmi Sita et al. 1979, Gupta et al. 1980, Kedharnath 1983, Kapoor and Sharma 1985, 1987, Beniwal and Singh 1990), by and large, rest of the commercial timbers have not received an adequate attention of plant breeders. This is perhaps due to the lack of thorough knowledge of chromosomal constitution of timber species with respect to the wood quality coupled with other information on the floral biology of these trees.

The information about the intraspecific polyploidy can also be utilized for the selection of suitable geographic races for future plantations and also in the proper understanding of the genetic make up of the timber species. In India 327 hardwood species are commercially exploited and account for nearly $75 \%$ of the total commercial wood, whereas rest of the wood comes from 11 commercially important soft wood species which are known cytologically and the processes involved in their evolution are quite understood (Mehra 1968).

Most of the earlier work on the cytology of Indian commercial hardwoods has resulted from the studies at Botany Departments of Punjab University, Chandigarh (Mehra 1976) and Punjabi Universtity, Patiala (Gill et al. 1981, 1982, 1989, Bir et al. 1982, Bir 1983, Bedi et al. 1985, Chatha and Bir 1987, 1988, Bedi 1990a). In addition many other workers have contributed to the cytology of commercial timbers by recording the chromosome numbers of regional floras, families or genera.

\section{Scope and methodology}

In this paper an attempt has been made to compile all the available information on the cytology and various cytological processes operative in the Indian hardwood timbers. The data pertaining to chromosomes have been documented from Darlington and Wylie (1955), Moore (1973, 1974, 1977), Mehra (1976), Löve (1965-1988), Fedorov (1969), Bir (1983-1988) and selected references from Biological Abstracts (1970 onwards).

\section{Results and discussion}

Todate cytological information in available for 252 species. From the cumulative data some general conclusions regarding the broad evolutionary patterns of Indian commercial timbers and their cytological status are discussed.

1 This paper is dedicated to Professor S. S. Bir, F. N. A., Department of Botany, Punjabi University, Patiala to commemorate his 40 years association with chromosome research (R. R. L Contribution No. 2060). 
Numerical variability

Analysis of data reveal that chromosome numbers for $70.03 \%$ (252 species) of Indian commercial timbers are known. The chromosome numbers vary from $2 \mathrm{n}=10$ (Santalum album) to $2 \mathrm{n}=196$ (Bischofia javanica). The average somatic number for hardwood timbers is computed to be 38.15 , which is significantly higher than the figure of 32.14 for tropical dicotyledons (Grant 1971) as a whole. The chromosome number $2 n=24$ is the most common being reported in as many as 50 taxa followed by $2 n=26$ (33 taxa) and $2 n=22$ (24 taxa). Except for few genera (Quercus, Castanopsis, Persea, Machilus, Ficus, Eucalyptus) which show constancy of chromosome numbers, chromosome stability in hardwood timbers is not so rigid as has been found in softwood timbers (Mehra 1968).

Table 1. Data on basic numbers in genera of Indian commercial hardwood timbers

\begin{tabular}{|c|c|}
\hline $\begin{array}{l}\text { Basic } \\
\text { number }\end{array}$ & Genera \\
\hline$x=5$ & Santalum (1) \\
\hline$x=6$ & Swietenia (1) \\
\hline$x=7$ & Bischofia, Bridelia, Cassia, Emblica, Excoecaria, Hopea, Kydia, Platanus and Shorea (9) \\
\hline$x=8$ & Carpinus, Cordia, Dillenia, Lagerstroemia, Mesua and Prunus (6) \\
\hline$x=9$ & $\begin{array}{l}\text { Aegle, Atalantia, Bruguiera, Butea, Casuarina, Feronia, Grewia, Hevea, Limonia, Miliusa, } \\
\text { Murraya, Polyalthia, Rhizophora, Schima and Zanthoxylum (15) }\end{array}$ \\
\hline$x=10$ & $\begin{array}{l}\text { Aesculus, Anisoptera, Berrya, Celtis, Chloroxylon, Dalbergia, Dipterocarpus, Dysoxylum, } \\
\text { Evodia, Grevillea, Heritiera, Mangifera and Vateria (13) }\end{array}$ \\
\hline$x=11$ & $\begin{array}{l}\text { Adina, Alstonia, Anthocephalus, Boswellia, Buchanania, Canthium, Cornus, Eucalyptus, } \\
\text { Gardenia, Holarrhena, Homalium, Hymenodictyon, Mallotus, Mitragyna, Morinda, Nyssa, } \\
\text { Pongamia, Protium, Pterocarpus, Sapium, Syzygium, Trewia, Wrightia and Xeromphis (24) }\end{array}$ \\
\hline$x=12$ & $\begin{array}{l}\text { Anogeissus, Castanopsis, Cedrela*, Ceiba, Cinnamomum, Cryptocarya, Diploknoma, } \\
\text { Duabanga, Hydnocarpus, Litsea, Machilus, Madhuca, Mimusops, Ougenia, Parrotiopsis, } \\
\text { Phoebe, Quercus, Robinia, Salmalia, Strychnos, Tamarindus, Tamarix, Terminalia, Vitex*, } \\
\text { Xylia and Zizyphus (26) }\end{array}$ \\
\hline$x=13$ & $\begin{array}{l}\text { Acacia, Acer, Albizzia, Barringtonia, Broussonetia, Canarium Careya, Cedrela*, Chukrasia, } \\
\text { Ehretia, Ficus, Garuga, Rhododendron, Thespesia and Toona (15) }\end{array}$ \\
\hline$x=14$ & $\begin{array}{l}\text { Alnus, Artocarpus, Azadirachta, Bauhinia, Betula, Boehmeria, Buxus, Holoptelea, Melia, } \\
\text { Moringa, Morus, Prosopis, Soymida and Ulmus (14) }\end{array}$ \\
\hline$x=15$ & Diospyros, Lamnea and Pistacia (3) \\
\hline$x=16$ & Bucklandia, Calophyllum, Filicium, Juglans, Schleichera, Spondias and Vitex* (7) \\
\hline$x=17$ & Callicarpa, Hardwickia and Vitex* (3) \\
\hline$x=18$ & Aphanamixis, Borassus, Radermchera* and Tectona (4) \\
\hline$x=19$ & Gmelina, Michelia, Populus, Pterospermum, Salix and Talauma (6) \\
\hline$x=20$ & Aglaia, Amoora, Pterocambium, Pterygota, Radermchera*, Sterculia and Stereospermum (7) \\
\hline$x=21$ & Erythrina (1) \\
\hline$x=23$ & Fraxinus, Gynocardia, Olea, Schrebera and Tetrameles (5) \\
\hline $\mathrm{x}=\mathbf{3 1}$ & Ailanthus* (1) \\
\hline$x=43$ & Ailanthus* (1) \\
\hline
\end{tabular}

* Genera with more than one base number.

The variability in base numbers $(x=5-21,23,31$ and 43$)$ is evident from Table 1 . The lowest being in Santalum $(\mathrm{x}=5)$ and the highest in Ailanthus $(\mathrm{x}=43)$. Base numbers in $67 \%$ of the timber genera fall in the range of $x=9-14$. Twelve is the commonest base number, being represented in 26 out of 158 genera. This observation is in line with Khosla and Sareen (1981) for their sample of world hardwood timbers. As many as $113(71.5 \%$ genera show base numbers $\mathrm{x}=11$ or above, this confirms the earlier observations on tropical (Mehra 1972, Khosla 1975, Khosla and Sareen 1978) as well as temperate (Grant 1958, Mangenot and Mangenot 1962) woody taxa. 
The average base number for Indian hardwood timbers is 12.95 which falls within the range of original basic mode (12 to 14) of modern woody genera (Stebbins 1971). Heterogeneity of base numbers among hardwood timbers is further supported by the fact that out of 62 families to which these timbers belong, only 25 are endowed with a single base number. There is cytological variability in hardwood timbers, but cytological stability of woody species is reported (Stebbins 1938, Darlington 1956).

\section{Synthesis of base numbers}

Keeping in view the current trend of treating $x=7$ as the original base number for angiosperms (Ehrendorfer et al. 1968, Walker 1972, Raven 1975, Khosla 1978) it is evident that base numbers $x=5,6,8-21,23,31$ and 43 for Indian hardwood timbers are of secondary origin. It seems that the variation in base numbers resulted through euploidy $(14,21$ and higher) followed by aneuploidy both at diploid and polyploid levels (Khosla and Sareen 1981). Further increase in variation was caused by euploidy at different levels. During the course of

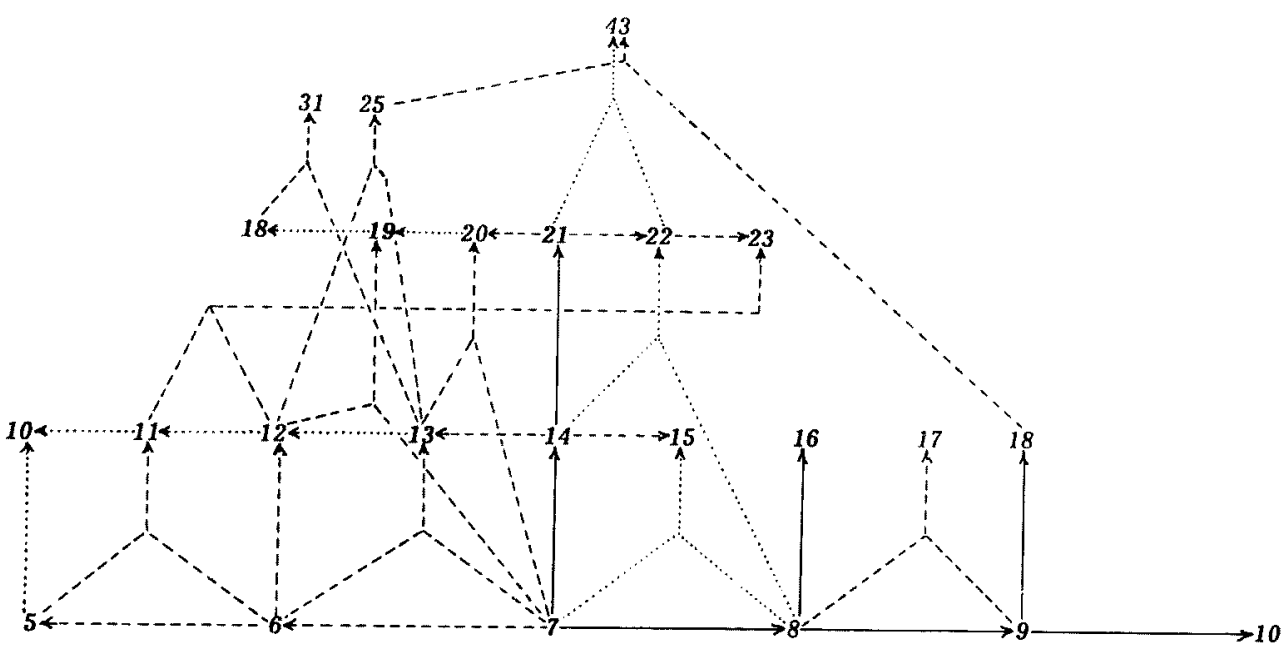

Fig. 1. Origin and inter-relationship of various base numbers in Indian commercial hardwoods.

(Redrawn from Ehrendorfer et al. 1968)

Definite relationship (— $\longrightarrow$; Probable relationship (---- );

Possible relationship $(\cdots \cdots \cdots \cdots)$.

evolution, diploid parents started becoming extinct and it was followed by the compounding of new numbers through amphiploidy. These allopolyploids after diplodization gave rise to the present day variation in this group of plants. However certain genera (Quercus, Eucalyptus, Machilus) preferred to evolve through chromosomal alterations and species hybridization. The glaring example of amphiploid origin of base numbers in timber species are seen in the origin of $x=19$ in Magnoliaceae and Salicaceae by the synthesis of 7 and 12 (Stebbins 1950). Similarly the origin of other odd numbers $(x=17,21,23,25,31,43)$ in present day hardwood timbers can be traced through appropriate combinations. The origin and interrelationship of various base numbers encountered in the Indian commercial hardwood timbers is illustrated in Fig. 1.

\section{Polyploidy}

Polyploidy has played an important role in the evolution of plants. For Indian commercial timbers the incidence of polyploidy is $33.3 \%$ ( 84 polyploids out of 252 species), which is significantly higher than the figure of $24.6 \%$ for Himalayan hardwoods (Mehra 1972) but 
is quite close to the percentage polyploidy $(30 \%)$ for world timbers (Khosla and Sareen 1981). Thus the earlier contention of Darlington (1937) and Stebbins (1950) about the rarity of polyploidy in woody taxa does not hold good for all the hardwood timbers, whereas it is an attribute of only a few genera (Eucalyptus, Quercus, Machilus, Ficus) and families.

Grade of polyploidy amongst the studied commercial hardwoods is quite variable i.e. $3 \mathrm{x}$ to $10 \mathrm{x}, 14 \mathrm{x}, 15 \mathrm{x}$ and $28 \mathrm{x}$. Among these, tetraploids are the most common $(56.9 \%)$ followed by hexaploids $(13.8 \%)$ and octaploid $(11.9 \%)$. Among polyploids, the highest percentage of tetraploids combine the characteristics of two different but closely allied diploid parents (de Wet 1980) and thus have greater chances of survival. The highest level of polyploidy i.e. 28x has been observed in Bischofia javanica.

The role of polyploidy in evolution at intrageneric level, is evident from the fact that out of 159 genera of commercial timbers known cytologically, interspecific polyploidy is recorded in the members of as many as 41 genera. They are: Dipterocarpus, Heritera, Hopea, 2x, 3x; Aegle, Aglaia, Alnus, Cedrela, Celtis, Erythrina, Hydnocarpus, Litsea, Prunus, Prosopis, Santalum, Strychnos, Wrightia, Xeromphis, 2x, 4x; Hymenodictyon, Lagerstroemia, Platamus, 2x, $6 \mathrm{x}$; Dysoxylum, 2x, 8x; Dillenia, 4x, 6x; Ceiba, 6x, 7x; Salmalia, 6x, 8x; Populus, Ulmus, 2x, $3 \mathrm{x}, 4 \mathrm{x}$; Aphanamixis, Terminalia, Toona, 2x, 4x, 6x; Acacia, Hevea, 2x, 4x, 8x; Canarium 2x, $6 \mathrm{x}, 8 \mathrm{x}$; Callicarpa, 2x, 8x, 10x; Diospyros, 2x, 3x, 4x, 6x; Acer, 2x, 4x, 6x, 8x; Syzygium, 2x, 3x, 4x, 5x, 6x; Zizyphus, 2x, 4x, 5x, 6x, 8x, 10x; Morus, 2x, 4x, 6x, 8x, 21x; Salix, 2x, 4x, 5x, 6x, $8 \mathrm{x}, 10 \mathrm{x}$; Emblica, 2x, 4x, 6x, 8x, 14x, 15x, and Swietenia, 2x, 4x, 6x, 7x, 8x, 9x, 10x, 18x.

The cumulative cytological data show that for 252 studied species, the intraspecific polyploidy exist for 36 species. They are: Heritiera littoralia, Hopea odorata, Populus alba, P. nigra $(2 \mathrm{x}, 3 \mathrm{x})$; Acacia leucophloea, Acer oblongum, Aegle marmelos, Cedrela serrata, Celtis australis, Erythrina suberosa, Hydnocarpus laurifolia, Morus laevigata, Prosopis cineraria, Salix tetrasperma, Santalum album, Strychnos nux-vomica, Terminalia belerica, Wrightia tinctoria, Xeromphis spinosa $(2 \mathrm{x}, 4 \mathrm{x})$; Diospyros ebenum, Hymenodictyon excelsum, Morus serrata, Platanus orientalis $(2 \mathrm{x}, 6 \mathrm{x})$; Dillenia indica $(4 \mathrm{x}, 6 \mathrm{x}) ;$ Acacia nilotica $(4 \mathrm{x}, 8 \mathrm{x})$; Ceiba pentendra $(6 \mathrm{x}, 7 \mathrm{x})$; Salmalia malabarica $(6 \mathrm{x}, 8 \mathrm{x})$; Swietenia macrophylla $(8 \mathrm{x}, 9 \mathrm{x})$; Callicarpa tomentosa $(8 \mathrm{x}, 10 \mathrm{x})$; Syzygium alternifolium $(2 \mathrm{x}, 3 \mathrm{x}, 4 \mathrm{x})$; Aphanamixis polystachya, Terminalia chebula, Toona ciliata $(2 \mathrm{x}, 4 \mathrm{x}, 6 \mathrm{x})$; Emblica officinalis $(4 \mathrm{x}, 8 \mathrm{x}, 14 \mathrm{x}, 15 \mathrm{x})$; Syzygium cumini $(2 \mathrm{x}$, $3 \mathrm{x}, 4 \mathrm{x}, 5 \mathrm{x}, 6 \mathrm{x})$ and Zizyphus jujuba $(2 \mathrm{x}, 4 \mathrm{x}, 5 \mathrm{x}, 6 \mathrm{x}, 8 \mathrm{x})$.

\section{Aneuploidy}

The important role of aneuploidy in the evolution of hardwood timbers is evident from the fact that in as many as 33 species the phenomenon is operative at diploid or polyploid levels. The species in which numerical changes have occured at diploid level are Wrightia tinctoria $(\mathrm{n}=10,11)$, Radermachera xylocarpa $(\mathrm{n}=18,20)$, Terminalia arjuna $(\mathrm{n}=12,13), T$. belerica $(\mathrm{n}=12,13), T$. chebula $(\mathrm{n}=12,13)$, Mallotus phillipinensis $(\mathrm{n}=11,12)$, Ougenia oojeinensis $(\mathrm{n}=11,12)$, Robinia pseudoacacia $(\mathrm{n}=10,12)$, Barringtonia acutangula $(\mathrm{n}=12,13)$, Homalium tomentosum $(\mathrm{n}=10,11)$, Madhuca indica $(\mathrm{n}=11,12)$, Ailanthus excelsa $(\mathrm{n}=31,43)$ and Vitex peduncularis $(\mathrm{n}=16,17)$. Whereas such changes at polyploid levels are seen in Alstonia scholaris $(\mathrm{n}=20,24)$ Ceiba pentendra $(\mathrm{n}=40,44)$ Salmalia malabarica $(\mathrm{n}=46,48)$, Dillenia indica $(\mathrm{n}=14,16)$, Bridelia retusa $(\mathrm{n}=13,14)$, Hevea braziliensis $(\mathrm{n}=17,18)$, Cassia fistula $(\mathrm{n}=12,13,14)$, Prosopis cineraria $(\mathrm{n}=26,28)$, Lagerstroemia speciosa $(\mathrm{n}=22,24)$, Cedrela serrata $(\mathrm{n}=26,28)$, Swietenia macrophylla $(\mathrm{n}=23,24), S$. mahagoni $(\mathrm{n}=27,28)$, Toona ciliata $(\mathrm{n}=26,28)$ and Callicarpa tomentosa $(\mathrm{n}=65,68)$. In the case of another 5 polyploid species namely, Hopea odorata $(\mathrm{n}=10)$, Strychnos nux-vomica $(\mathrm{n}=22)$, Emblica officinalis $(\mathrm{n}=26,52)$, Evodia fraxinifolia $(\mathrm{n}=39)$ and Zanthoxylum budrunga $(\mathrm{n}=34)$, the origin of these numbers is attributed only to the aneuploid drops at polyploid levels. 


\section{Chromosome size and recombination index}

In comparison to conifers, the hardwood timbers in general have small sized chromosomes. Studies by Mehra (1972) and Bedi et al. (1985) showed that among hardwood trees, percentage of large sized chromosomes is less than $4 \%$ and $2.7 \%$, respectively. The relatively large sized chromosomes which are an attribute of certain unrelated genera in different families are encountered in Miliusa (Anonaceae), Michelia and Talauma (Magnoliaceae), Terminalia (Conbretaceae), Cordia dichotoma (Boraginaceae), Litsea polyantha (Lauraceae), Syzygium cumini (Myrtaceae) only, while majority of the timber species are having small sized chromosomes.

Recombination index, which effects the natural variability of a species is the product of haploid chromosome number and average chaisma frequency of a meiotic cell (Darlington 1973) and is generally higher in the long lived perennial plants. In some tropical timber genera the low recombination index due to small size of chromosomes is compensated by the high chromosome numbers. It is also supported by the fact that the average somatic chromosome number for commercial timbers is very high (38.15). In certain other species with low chromosome numbers, coupled with small sized chromosomes the lowered recombination index has logically been balanced by the out crossing behaviour of such species (Khosla and Sareen 198i).

\section{$B$-chromosomes}

B-chromosomes are reported to occur in 58 hardwood species. Out of these, nine species namely Diospyros ebenum, $2 \mathrm{n}=30+0-2 \mathrm{~B} ;$ Erythrina suberosa, $2 \mathrm{n}=42+0-2 \mathrm{~B}$; Machilus macrantha, $2 \mathrm{n}=24+0-1 \mathrm{~B}, M$. odoratissima, $2 \mathrm{n}=24+0-2 \mathrm{~B} ;$ Santalum album, $2 \mathrm{n}=20+0-1 \mathrm{~B}$; Syzygium cumini, $2 \mathrm{n}=22+0-3 \mathrm{~B} ;$ Tamarindus indca, $2 \mathrm{n}=24+0-4 \mathrm{~B} ;$ Terminalia arjuna $2 \mathrm{n}=$ $24+0-2 \mathrm{~B}$ and Zizyphus jujuba, $2 \mathrm{n}=48+1 \mathrm{~B}$; are timbers of commercial importance.

In timbers, it seems that the polyploidy disfavours the existence of B-chromosomes because out of 9 species with Bs all are diploids except for Zizyphus jujuba and Santalum album, which are tetraploids. This supports the view that B-chromosomes are more frequent among diploids than polyploids (Lewis and John 1963). The number of Bs in these species vary from 0-4. Mehra (1972) considers the occurrence of Bs in woody species as one of the evolutionary processes in the hardwoods. Jones (1975) has discussed the instances in herbaceous plants and animals, where the Bs are known to cause both favourable and unfavourable effects. Thus to record such effects of accessary chromosomes in the timber species is of immence importance for locating variability for future breeding programmes,

\section{Cytomixis}

It is a fairly common phenomenon as has been recorded in 8 commercial timbers (Castanopsis tribuloides, Cordia dichotoma, Cornus oblonga, Gmelina arborea, Olea glandulifera, Quercus semecarpifolia, Syzygium cumini and Wrightia tinctoria). Various causes have been assigned to its occurence (Bedi 1990b) and the phenomenon results in both hypo-and hyperploid cells. Intrestingly the phenomenon is more common during the early stages of meiosis but has been recorded to occur even at telophase-II (Chatha and Bir 1988). The role of cytomixis in the origin of aneuploids, polyploids (Sarvella 1958) and B-chromosomes (Cheng et al. 1975), is yet to be fully confirmed. But the conclusions pertaining to the evolutionary significance of cytomixis requires karyological studies.

\section{Chromosome number verses growth characteristics}

Keeping in view of the great intraspecific chromosomal variation (euploidy, aneuploidy, B-chromosomes, cytomixis, etc.) existing in commercial timbers, it is highly desirable to study the wood characteristics of taxa showing such variations. Earlier such studies were conducted by different workers on only few of the commercial timbers.

Mehra and Hans (1972) and Khosla (1975) on the basis of their observations on natural diploid and polyploid timbers concluded that the diploids are superior in wood density and 
hardness. The former are of the opinion that growth rate is higher in polyploids over diploids. According to Khosla (1975) there is no significant difference in the growth rates of diploids and polyploids.

Gill et al. (1982) by their studies on Terminalia chebula concluded that the denisty of wood is highest in diploid and lowest in hexaploid cytotypes, whereas the tetraploid cytotypes show intermediate value.

On the other hand in Syzygium cumini (Gill et al. 1989) the density and specific gravity of wood remain unchanged in $2 x, 4 x$ and $6 x$ cytotypes, but diploids definitely show better growth rate and biomass production than the polyloid cytotypes. Keeping in view the varied response regarding the growth rate and wood characteristics in different species to natural polyploidy, it is concluded that like temperate genera (Wright 1976) there appears to be no consistent relationship between chromosome number and economic traits of tropical hardwood timbers. Thus by inducing polyploidy for timber improvement, a plant breeder may evolve a type with new traits, which may or may not be economicaly useful than its diploid progenitor.

\section{Summary}

Numerical variability in hardwood timbers is observed from the great variation in chromosome numbers $(2 n=10$ to $2 n=196)$ as well as basic numbers $(x=5-21,23,31$ and 43$)$. The most commonly represented chromosome number is $2 n=24$. Treating $x=7$ as the original base number for angiosperms, the possible role of polyploidy and/or aneuploidy in the origin of existing heterogeneity in the present day base numbers of Indian commercial timbers is discussed. Incidence of polyloidy is $33.3 \%$. Amongst polyploids the tetraploids are the most common. Intraspecific polyploidy exists in 36 species. The highest level of ploidy $28 \mathrm{x}$ is in Bischofia javanica. The average somatic chromosome number in the present sample of timbers is quite high (38.15), this duly compensates the low recombination index resulting due to small sized chromosomes, a characteristic of majority of the hardwood timbers. Other phenomena of cytological interest are the existence of B-chromosomes ( 9 species) and cytomixis ( 8 species). There appears to be no consistent relationship between chromosome number and economic usefulness of tropical hardwood timbers.

\section{Acknowledgements}

Author is graterful to Dr. R. S. Kapil, Director of the laboratory for the facilities and encouragement.

\section{References}

Bedi, Y. S. 1990a. Cytology of hardwoods. Proc. Indian Acad. Sci. 100B: 91-95.

- 1990b. Cytomixis in woody species. Proc. Indian Acad. Sci. 100B: 233-238.

-, Gill, B. S. and Bir, S. S. 1985. Cytological evolution in the woody taxa of Gamopetalae and Monochlamydeae. J. Cytol. Genet. 20: 162-203.

Beniwal, B. S. and Singh, N. B. 1990. Genetic improvement of forest trees in Arunachal Pradesh. Ind. For. 106: 3-10.

Bir, S. S. 1983. Reminiscences of a cytologist. Acta. Bot. Indica 11: i-xxi.

- (ed.) 1983-1988. SOCGI Plant Chromosome number reports I-VII. J. Cytol. Genet. 18-23.

-, Gill, B. S., Bedi, Y. S. and Singhal, V. K. 1982. Evolutionary status of the woody taxa of Garhwal Himalaya. In: Improvement of Forest Biomass pp. 81-96 (P. K. Khosla, ed.). I. S. T. S. Solan.

Chatha, G. S. and Bir, S. S. 1987. Population analysis of some woody species from Palni Hills, South India. J. Cytol. Genet. 22: 83-94.

— and - 1988. Cytology and distribution pattern of some woody species from Palni Hills, South India. In: 
Glimpses of Cytogenetics in India 1: 222-229 (S. S. Bir and G. S. Chatha eds.) S. O. C. G. I. India. Cheng, K. C., Nieh, H. W., Yang, C. L., Chou, I. S. and Chen, J. S. 1975. Light and electron microscopical observations on cytomixis and the study of its relation to variation and evolution. Acta Bot. Sin. 47: $60-69$.

Darlington, C. D. 1937. Recent Advances in Cytology. Churchill and Co., London.

- 1956. Chromosome Botany. Churchill and Co., London.

- 1973. Chromosome Botany and Origin of Cultivated Plants. George Allen and Unwin, London.

- and Wylie, A. P. 1955. Chromosome Atlas of Flowering Plants. George Allen and Unwin, London.

Ehrendorfer, F., Krendl, F., Habeler, E. and Sauer, W. 1968. Chromosome numbers and evolution in primitive angiosperms. Taxon 17: 337-353.

Fedorov An. A. (ed.) 1969. Chromosome Numbers of Flowering Plants. Acad. of Sci. U. S. S. R., Leningrad. Gill, B. S., Bir, S. S. and Singhal, V. K. 1982. Cytogenetics of some timber species of Terminalia Linn. (Combretaceae). Proc. Indian natn. Sci. Acad. 48B: 779-790.

-, -, Bedi, Y.S. and Singhal, V. K. 1981. Cytological evolution in the woody species of the Central Indian forests. In: 4th All India Congr. of Cytol. Genet. (Abs.) pp. 154-155 Bhagalpur.

_, Singhal, V. K. and Kaur, A. 1989. Genetic variability in trees of social Forestry-I Eugenia jambolana Lamk. In: Plant Science Research in India pp. 279-284 (M. L. Trivedi, B. S. Gill and S. S. Saini eds.) Today and Tomorrow Print. and Publ., Delhi.

Grant, V. 1958. The regulation of recombination in plants. Cold spring Symp. Quant. Biol. 23: $337-363$. - 1971. Plant Speciation. Columbia Univ., New York.

Gupta, P. K., Nadgir, A. L., Mascarenhas, A. F. and Jagannathan, V. 1980. Tissue culture of forest trees. Clonal multiplication of Tectona grandis (Teak) by tissue culture. Pl. Sci. Lett. 17: 259-268

Jones, R. N. 1975. B-chromosome systems in flowering plants and animal species. Intern. Rev. Cytol. 40: 1-100.

Kapoor, M. L. and Sharma, V. K. 1985. Experimentally synthesized allotetraploids in Eucalyptus. Silv. Genet. 34: 19-22.

— and - 1987. Experimentally synthesized allotriploids in Eucalyptus. J. Tree Sci. 6: 84-88.

Kedharnath, S. 1983. Genetics and forest tree breeding. In: Genetical Research in India pp. 181-190 (P. L. Jaiswal and A. M. Wadhwani eds.) I. C. A. R., New Delhi.

Khosla, P. K. 1975. Chromosomal evolution in commercial hardwoods. Nucleus 18: 54-60.

- 1978. Cytosytematics of some hardwood families. Nucleus 21: 211-218.

- and Sareen, T. S. 1978. Chromosomal conspectus of Indian hardwood timbers. Indian J. Forest. 1: 169178.

- and - 1981. Cytological characteristics and chromosomal systems of forest trees. In: Advances in Forest Genetics pp. 117-156 (P. K. Khosla ed.) Ambica Publ., New Delhi.

Lakshmi Sita, G., Raghava Rann N. V. and Vaidyanathan, C. S. 1979. Differentiation of embryoids and plantlets from shoot callus of sandal wood. Pl. Sci. Lett. 16: 265.

Lewis, K. R. and John, B. 1963. Chromosome Marker. Churchill and Co., London.

Löve, A. (ed.) 1965-1988. IOPB Chromosome number reports I-LXXXXXI. Taxon 1-37.

Mangenot, S. and Mangenot, G. 1962. Enquete sur les nombres chromosomiques dans une collection d'especes tropicales. Rev. Cytol. Biol. Veget. 25: 411-447.

Mehra, P. N. 1968. Cytogentical evolution in confifters. Ind. J. Genet. Pl. Br. 28: 97-102.

- 1972. Cytogenetical evolution of hardwoods. Nucleus 15: 64-83.

- 1976. Cytology of Himalayan Hardwoods. Sre Saraswaty Press, Calcutta.

- and Hans, A. S. 1972. Comparison of diploid and natural polyploid hardwoods. J. Indian Bot. Soc. 51: 319-325.

Moore, R. J. (ed.) 1973. Index to Plant Chromosome Numbers 1967-1971 Regnum Veg. 90.

- 1974. Index to Plant Chromosome Numbers 1972. Regnum Veg. 91.

- 1977. Index to Plant Chromosome Numbers 1973-1974. Regnum Veg. 96.

Raven, P. H. 1975. The bases of angiosperm phylogeny-Cytology. Ann. Missouri Bot. Gard. 62: 724-764.

Sarvella, P. 1958. Cytomixis and loss of chromosomes in meiotic and somatic cells of Gossypium. Cytologia 23: 14-24.

Stebbins, G. L. Jr. 1938. Cytological characteristics associated with the different growth habits in the dicotyledons. Amer. J. Bot. 25: 189-198.

- 1950. Variation and Evolution in Plants. Columbia Univ. Biol. Serv., Columbia.

- 1971. Chromosomal Evolution in Higher Plants. Edward Arnold Ltd., London.

Venkatesh, C.S. and Sharma, V. K. 1977. Rapid growth rate and higher yield potential of heterotic Eucalyptus species hybrids FRI-4 and FRI-5. Indian Forester 103: 795-802. 
Walker, J. W. 1972. Chromosome numbers, phylogeny, phytogeography of the Annonaceae and their bearing on the original basic numbers of angiosperms. Taxon 21: 57-65.

De Wet, J. M. J. 1980. Origins of polyploids. In: Polyploidy Biological Relevance. pp. 3-15 (W. H. Lewis ed.) Plenum Publ. Crop., New York.

Wright, J. W. 1976. Introduction to Forest Genetics. Academic press, London.

Note: List of 327 Indian commercial timbers (Hardwoods) along with common names and chromosome numbers is available from auther upon request. 